\title{
Çölyak hastalığı ön tanısı almış bireylerde HLA-DQ2 ve HLA-DQ8 genotip sıklıkları
}

\section{Frequencies of HLA-DQ2/DQ8 genotypes in patients prediagnosed as Celiac disease}

\author{
Elçin Latife Kurtoğlu, İbrahim Tekedereli \\ İnönü Üniversitesi Tıp Fakültesi, Tıbbi Biyoloji ve Genetik Anabilim Dalı, Malatya, Turkey
}

\begin{abstract}
Özet
Amaç: Çölyak hastalığı yaygın, ailesel, otoimmün bir gastrointestinal hastalıktır. Bu durum, buğday, çavdar ve arpada bulunan diyetteki protein glutene karşı hassasiyetten kaynaklanır. Çölyak hastalığı insan lökosit antijenleriyle (HLA) güçlü bir genetik ilişkiye sahiptir. Çölyak hastalığı için birincil duyarlılık genotipi HLADQA $1{ }^{*} 05$ ve $\mathrm{DQB} 1{ }^{*} 02$ 'den oluşan HLA-DQ2'dir, vakaların geri kalan kısmı HLA-DQA1*03 ve DQB1*03:02'den oluşan HLA-DQ8 ile ilişkilidir. Bu çalışmanın amacı, Malatya ilinde çölyak ön tanısı almış çocuk hastalarda DQ2 ve DQ8 genotiplerinin sıklığını araştırmaktır.
\end{abstract}

Gereç ve Yöntem: 578 bireyden (338 kadın/240 erkek) DNA örnekleri HLA-DQA1 ve DQB1 için SSP-PCR yöntemine göre genotiplenmiştir.

Bulgular: 578 olgunun 304'ünde (\%52.59) HLA-DQ2, 86'sında (\%14.87) HLA-DQ8, 28'inde (\%4.84) HLA-DQ2 /DQ8 tespit edilmiştir ve 160 hastanın ise (\%27.68) DQ2 veya DQ8 genotiplerinden herhangi birine sahip olmadığı görülmüştür. En sık rastlanan alleller DQA $1{ }^{*} 05$ (\%76.64) ve DQB1*02 (\%61.41) olarak belirlenmiştir.

Sonuç: Sonuç olarak; çalışmamızdaki DQ2/DQ8 genotiplerinin sıklıklarının, literatür ile benzer olduğu tespit edilmiştir.

Anahtar Sözcükler: Çölyak hastalığı; HLA-DQ2; HLA-DQ8.

Con ölyak hastalığı $(\mathrm{ÇH);} \mathrm{buğday,} \mathrm{arpa,} \mathrm{çavdar} \mathrm{ve} \mathrm{yulaf} \mathrm{gibi}$ tahıllardaki glutene karşı intoleransın olduğu bireylerde gôrülen, ince barsağın malabsorbsiyonu ve mukozal hasarına göre karakterize edilen yaygın bir poligenik ve multifaktöryel bozukluktur. ${ }^{[1,2]}$ Gluten duyarlı enteropati olarak da isimlendirilen $\mathrm{C} \mathrm{H}$, insandaki en yaygın besin duyarlı entropatidir ve kronik otoimmün gastrointestinal bir hastalıktır. ${ }^{[2-5]} \mathrm{Ç}^{\mathrm{H}}$ 'nin genellikle çocukluk çağında başladığı varsayılmakla birlikte, son

\begin{abstract}
Introduction: Celiac disease is a common, familial, autoimmune gastrointestinal disease. It is caused by sensitivity to the dietary protein gluten, which is present in wheat, rye, and barley. Celiac disease has a strong genetic association with human leukocyte antigens ( $H L A)$. The primary susceptibility allele for Celiac disease is $\mathrm{HLA}-\mathrm{DQ} 2$ which is composed of $\mathrm{HLA}-\mathrm{DQA} 1{ }^{*} 05$ and $\mathrm{DQB} 1{ }^{*} 02$, rest of the cases is related to HLA-DQ8 that is composed of HLA-DQA $1{ }^{*} 03$ DQB $1{ }^{*} 03: 02$. The aim of the present study was to investigate the prevalence of the DQ2 and DQ8 genotypes in children with prediagnosed as celiac disease in city of Malatya, Turkey.

Methods: DNA samples from 578 individuals (338 female, 240 male) were genotyped for HLA DQA1 and DQB1 based on SSP-PCR method. Results: Among the 578 cases, 304 (52.59\%) had the genotype HLADQ2 and 86 (14.87\%) had HLA-DQ8, 28 (4.84\%) had HLA-DQ2/DQ8, and $160(27.68 \%)$ did not have any of these genotypes. The most common alleles in children genotyped for in Malatya were DQA $1 * 05$ (76.64\%) and DQB1*02 (61.41\%).

Discussion and Conclusion: In conclusion, the frequencies of the DQ2/DQ8 genotypes in our study are similar to those reported in Turkey, previously.

Keywords: Celiac disease; HLA-DQ2; HLA-DQ8.
\end{abstract}

zamanlarda yetişkinlerde de gelişebildiği öne sürülmektedir. ${ }^{[6]}$ ÇH klasik, atipik, sessiz ve latent gibi farklı klinik formlarda bulunabilir. ${ }^{[3]}$ ÇH'nin prevalansı asemptomatik hastaların çok sayıda olması nedeniyle tam olarak tahmin edilememektedir. [7] Genel popülasyondaki ÇH prevalansı yaklaşık 1:250 olarak bildirimiştir. Batı ülkelerinde ise ÇH'da semptomik vakaların asemptomatik vakalara oranı 1:5-1:7 civarındadır. ${ }^{[4,7]}$ Hastalığın gelişmesi çevresel, genetik ve immünolojik faktörler ta- 
rafından belirlenmektedir. ${ }^{[1,3,6,7]}$ Hastalığın moleküler temeli henüz çok açık olmamasına rağmen, moleküler mekanizmanın insan lökosit antijeni (Human Leucocyte Antigen; HLA) moleküllerine gluten peptidlerin bağlanmasını ve sonrasında T hücreler tarafından spesifik olarak tanımayı içeren bir dizi immünolojik reaksiyonun başlamasını içerdiği düşünülmektedir. ${ }^{[8]} \mathrm{Bu}$ nedenle ÇH'nın genetik olarak yatkın olan bireylerde ortaya çıkan, T hücre aracılı bir hastalık olduğu sonucuna varılmaktadır. ${ }^{[2]}$ Aile ve populasyon çalışmaları ÇH ve 6 . kromozom üzerinde yer alan HLA-DQ lokusundaki genler arasında çok güçlü bir ilişki olduğunu göstermiştir. ${ }^{[3,9,10]}$ "The European Genetic Cluster on Celiac Disease" de doğrulandığı gibi ÇH çoğunlukla HLA-DQ2 (HLA-DQA 1*05, DQB1*02 allellerince kodlanan) pozitif bireylerde gelişirken, kalan hastaların çoğu ise HLA-DQ8 (DQA1*03, DQB1*0302) moleküllerini ifade etmektedirler. ${ }^{[2,11,12]}$ ÇH ile ilişkili olduğu düşünülen söz konusu HLA heterodimerlerinin alfa zinciri, HLA-DQA1 genleri tarafından kodlanırken, beta zinciri ise HLA-DQB1 genleri tarafından kodlanmaktadır. ${ }^{[13]} \mathrm{DQ} 2$ heterodimer varlığı ÇH'na sahip kişilerin \%90'ında görülürken, genel populasyonda ise \%30-40 oranında görülmektedir. ${ }^{[13-15]} \mathrm{HLA}-\mathrm{DQ} 2$ olmaksızın yalnızca HLA-DQ8 heterodimerlerine sahip bireylerin ise \%3-8'inde ÇH görülebilmektedir. ${ }^{[16]} \mathrm{HLA}-\mathrm{DQ} 2$ ve HLA-DQ8 negatif bireylerde ise $\mathrm{ÇH}$ gelişmesi son derece nadirdir. ${ }^{[6,11,17]}$ Buna ek olarak, komplike ÇH'na sahip hastalar arasında HLA-DQ2 genotipi ile birlikte HLA-DQB1*02 allelinin homozigotluğunun artmış bir frekansı olduğunu belirten çalışmalar bulunmaktadır. ${ }^{[15,18]}$ Belirlenen güçlü ilişki nedeniyle çoğu merkezde HLA tipleme, ÇH için genetik bir test olarak rutin olarak kullanılmaktadır. ${ }^{[1]]}$ Ancak HLA gruplarının (DQ2 ve DQ8 genlerinin) frekansı/prevalansı farklı populasyonlarda önemli ölçüde farklı olması nedeniyle bu genlerin tanıdaki kullanımı da populasyonlar arasında değişiklik gösterebilir ${ }^{[3,9,16]}$ ÇH için HLA testinin tanı koymadaki önemi tam olarak belli olmaması gerçeğine rağmen genellikle kesin olarak belirlenmemiş vakaların tanımlanmasına yardımcl olabileceği düşünülmektedir. ${ }^{[11]}$

Bu retrospektif çalışma ile (Megiorni ve ark. tarafından sunulan HLA nomenklatürüne uygun olarak) HLA-DQ2/DQ8 tiplemesi yapılan ÇH'dan elde edilen verilerin değerlendirilmesi amaçlanmıştır.

\section{Gereç ve Yöntem}

Bu çalışma, 2014-2016 tarihleri arasında, çölyak ön tanısı ile İnönü Üniversitesi, Turgut Özal Tıp Merkezi, Genetik Hastalıklar Tanı Merkezi'nde HLA tiplendirme testi yapılan (338 kız/240 erkek) hastayı kapsamaktadır. Hastaların yaşları 1-17 arasında değişmektedir. Genomik DNA, 2 ml priferik kandan otomatik DNA izolasyon cihazı ile izole edilmiştir (Qiagen BioRobot EZ1). Bu çalışmada, farklı alt tipleri ile birlikte HLA-DQA1 ve HLA-DQB1 allelleri tiplendirilmiştir. Bunun için diziye özgü primer-polimeraz zincir reaksiyonu (Sequence Specific Primers -Polymerase Chain Reaction, SSP-PCR) yöntemi kullanılmıştır (Olerup SSP AB, Sweden). İşlemler üreticinin belirlediği protole göre yapılmış olup kısaca, her hasta için 18 farklı primerin bu- lunduğu kuyucuklara $5 \mu \mathrm{ldH} 2 \mathrm{O}, 3 \mu \mathrm{l}$ mix, $0.08 \mu \mathrm{l} \mathrm{Taq} \mathrm{DNA} \mathrm{poli-}$ meraz ve $2 \mu \mathrm{l}$ DNA eklenmiştir. PCR koşulları ise, $94^{\circ} \mathrm{C}$ 'de $2 \mathrm{dk}$ ( 1 döngü), $94^{\circ} \mathrm{C}^{\prime}$ de $10 \mathrm{sn}, 65^{\circ} \mathrm{C}^{\prime}$ de $60 \mathrm{sn}$ (10 döngü), $94^{\circ} \mathrm{C}^{\prime}$ de $10 \mathrm{sn}$, $61^{\circ} \mathrm{C}$ 'de $50 \mathrm{sn}, 72^{\circ} \mathrm{C}$ 'de $30 \mathrm{sn}$ (20 döngü) şeklinde ayarlanmıştır. PCR reaksiyonu sonunda elde edilen PCR ürünleri \%2'lik agaroz jele yüklenmiş ve 110 voltta $20 \mathrm{dk}$ yürütülmüştür. Bu süre sonunda ise jeller UV ışık altında analiz edilmiştir. Analiz sonuçları DQA ${ }^{*} 05$ ve $\mathrm{DQB1}{ }^{*} 02$ allellerine sahip bireylerin $\mathrm{DQ} 2$ genotipini taşıdıkları ve DQA $1{ }^{*} 03$ ile $\mathrm{DQB} 1{ }^{*} 03: 02$ allellerini taşıyan bireylerin ise DQ8 genotipine sahip olduğu şeklinde yorumlanmıştır. DQA1*05, DQB1*02, DQA1*03, DQB1*03:02 allelleri dışında ayrıca DQA 1*02:01, DQB1*04, DQB1*06 allellerinin tespiti de gerçekleştirilmiş̧ir. Bu çalışmada allellerin homozigotluk durumu araştırılamamıştır. Genotip ve allel frekansları için tanımlayıcı istatistiksel ölçütler kullanılmıştır, sayı ve yüzde olarak ifade edilmiştir.

\section{Bulgular}

Çalışmamızın sonuçlarına göre 578 hastanın DQ2 ve DQ8 allel frekansı belirlenmiştir (Tablo 1). 578 hastanın 304'ü (\%52.59) yalnız HLA-DQ2 genotipine sahip iken 86'sının (\%14.87) yalnız HLA-DQ8 genotipine sahip olduğu belirlenmiştir. 28 (\%4.84) hasta ise HLA-DQ2 ve DQ8'in birlikte varlığı tespit edilirken, 160 (\%27.68) hastanın ise bu genotiplerden herhangi birine sahip

Tablo 1. Çölyak ön tanısı alan hastalardaki genotip dağılımları

$$
\mathrm{n}=\mathbf{5 7 8}
$$

\begin{tabular}{lcc}
\cline { 2 - 3 } Genotipler & Sayı & Yüzde \\
\hline DQ2 & 304 & 52.59 \\
DQ8 & 86 & 14.87 \\
DQ2/DQ8 & 28 & 4.84 \\
DQ2/DQ8 negatif & 160 & 27.68 \\
\hline
\end{tabular}

n: Hasta sayısı.

Tablo 2. Çölyak ön tanısı alan hastalardaki Allel dağılımları

$$
\mathrm{n}=\mathbf{5 7 8}
$$

\begin{tabular}{lcc} 
Allel & Sayı & Yüzde \\
\hline HLA-DQA1 & & \\
DQA $1{ }^{* 02: 01}$ & 112 & 19.37 \\
DQA $1{ }^{* 03}$ & 151 & 26.12 \\
DQA1*05 & 443 & 76.64 \\
HLA-DQB1 & & \\
DQB1 ${ }^{* 02}$ & 355 & 61.41 \\
DQB1 ${ }^{* 03: 02}$ & 119 & 20.58 \\
DQB1 ${ }^{* 04}$ & 36 & 6.22 \\
DQB1 ${ }^{* 06}$ & 12 & 2.07
\end{tabular}

n: Hasta sayısı. 
olmadığı belirlenmiştir. Bu sonuçlara göre hastaların büyük çoğunluğunda olması beklenen ve hastalığın ortaya çıkmasında önemli katkısının olduğu belirtilen HLA-DQA $1{ }^{*} 05$ alleli ise \%76.64 frekansında tespit edilmiştir. Sırasıyla tespit edilen diğer alleller ise 355 (\%61.41) hastada $\mathrm{DQB1}{ }^{*} 02,151$ (\%26.12) hasta $\mathrm{DQA} 1 * 03,119(\% 20.58)$ hastada DQB1*03:02 olarak belirlenmiştir. Malatya ilindeki çölyak ön tanısı alan çocuklarda en yaygın olarak görülen allel ise $\mathrm{DQA} 1{ }^{*} 05$ ve $\mathrm{DQB} 1{ }^{*} 02$ olarak belirlenmiştir. Çölyak hastalığı ile ilişkili olan diğer alleller ise DQA $1 * 02$ (\%19.37), DQB1*06 (\%2.07) ve DQB1*04 (\%6.22) olarak belirlenmiştir (Tablo 2).

\section{Tartışma}

Çölyak hastalığında genotip belirlenmesi, hastalığa yatkınlığın ve hastalığın ilerleyişinin tahmininde yardımcıdır. ${ }^{[14]}$ Çölyak hastalığında, DQ2 majör yatkınlık faktörüyken, DQ8 ise DQ2'den bağımsız olarak küçük bir risk eklemektedir. Gluten epitopları, DQ2 ve DQ8 tarafından seçilerek çölyak hastalığına sahip hastaların barsak $T$ hücreleri tarafından tanınmaktadır. ${ }^{[12]}$ Literatür bilgileri ışığında yapılan HLA-DQ2 ve DQ8 tiplendirmesi sonucunda ulaşılan sonuçlara göre ÇH ön tanısı alan hastalarımızın \%52.59'u DQ2 genotipine sahipken \%14.87'si DQ8 genotipine sahiptir. Bizim sonuçlarımızdan farklı olarak Kuloğlu ve ark.nın ülkemizde yaptığı çölyak hastalığına sahip 75 çocuğun HLA tiplemesi sonuçlarına göre ise bu hastalarda DQ2 prevalansı \%84.7 olarak tespit edilirken, DQ8 ise \%15.3 olarak belirlenmiştir. ${ }^{[3]} \mathrm{Bu}$ çalışmadaki DQ2 oranları bizim çalışmamızın sonuçlarından yüksek olarak bulunurken, DQ8 oranları ise bizim çalışma sonuçlarımıza yakın olarak bulunmuştur. Türkiye'de yapılan bir başka çalışmada ise Tüysüz ve ark. çölyak hastalığına sahip 55 çocukta en yüksek prevalansa sahip allelleri DQ2 heterodimerini oluşturan DQB1*02 (\%64.5) ve DQA $1 * 05$ (\%51) olarak tespit etmişlerdir. Bu alleleri ise sırasıyla DQ8 heterodimerini oluşturan DQA $1 * 03(\% 16.4)$ ve DQB1*03:02 (\%17.3) takip etmiştir. ${ }^{[10]}$ Tüysüz ve ark.dan farklı olarak bizim çalışma sonuçlarımıza göre en fazla görülen alleller arasında ilk sırayı DQA 1*05 (\%76.64) almaktadır. Buna ek olarak DQ8 görülme sıklığı, adı geçen çalışmanın sonuçlarından daha yüksek olarak tespit edilmiştir. Tümer ve ark.nın çalışmalarında, çölyak hastalığına sahip 33 çocuğun HLA tiplemesi sonucuna göre DQ2 genotipinin oranı bizim çalışmamızın sonuçlarına yakın olarak, \%52 olarak tespit edilmiştir. ${ }^{[19]}$ Ülkemiz dışında 2010 yılında Walkowiak ve ark. nın Polonya'da yaptığı bir çalışmanın sonuçlarına göre genel populasyonda HLA-DQ2 \%28.5 olarak tespit edilirken, HLADQ8 ise \%10 olarak tespit edilmiştir. ${ }^{[5]}$ Brezilya'da yapılan bir çalışmada 73 vaka arasından 50'si (\%68.5) DQ2 genotipine sahipken, 13 vakanın ise (\%17.8) DQ8 genotipine sahip olduğu rapor edilmiştir. Hastaların 5'i (\%6.8) ise DQ2+DQ8 genotipine sahip iken 5 vaka bu genotiplerden hiçbirini taşımazken, DQB1*02 en sık allel olarak bulunmuştur (\%94). ${ }^{[16]}$ Çölyak hastalığına sahip 19 bedevi ailesinde yapılan HLA DQA1-DQB1 genotiplemesi sonucunda 4 hastada DQ8 genotipi görülürken, 9 hastada hem DQ2 hem DQ8 genotipi görülmüştür ve 4 hastada ise DQA $1{ }^{*} 05$ olmaksızın DQB1*02'den bir kopya bulunmaktadır. ${ }^{[4]}$ Cintado ve ark.nın 22 Kübalı çölyak hastasında yaptığı çalışmada DQA 1*0501 sıkığı \%86.3 iken, DQB1*02 $\% 90.2$ ve her iki allelin birlikteliği (DQ2) ise \%86.3 olarak tespit edilmiştir. ${ }^{[20]}$ Megiorni ve ark. tarafından 437 Çölyak hastasının \%91'inin DQ2 ve/veya DQ8 heterodimerlerinden birini taşıdığı tespit edilmiştir. ${ }^{[11]}$ Bir başka çalışmanın sonuçlarına göre ise hastaların \%64'ü DQ2 ( $55 \beta 2$ ) heterodimerini taşırken, $\% 13.5^{\prime} \mathrm{i}$ ise yalnızca DQ8 heterodimerini taşımaktadır. Bununla birlikte hastaların \%95'inde DQB1*02 alleli olduğu tespit edilmiş ve bu allelin homozigot olarak bulunmasının bir artmış risk ilerlemesine neden olabileceği vurgulanmıştır. ${ }^{[15]} \mathrm{Bu}$ çalışmaya benzer şekilde sayısız çalışmada DQB1*02 homozigotluğunun, genellikle hastalığın artmış riski ve daha agresif formları ile ilişkili olabileceği doğrulanmıştır. ${ }^{[13]}$ Alarida ve ark. çölyak hastalığına sahip 31 Libyalı çocuğun DQ2 ve DQ8 genotiplemesini yapmış ve çalışmanın sonuçlarına göre DQ2, 32 homozigot genotipi \%32 oranında saptanırken, DQ2 heterozigot \%52 oranında tespit edilmiştir. Yalnızca DQ8 genotipi ise $\% 3$ oranında olarak kaydedilmiştir. ${ }^{[9]}$ Bunların dışında Megiorni'nin bir derlemesinde, çölyak otoimmünitesinin özellikle DQ2, DQ8 ve DQB1*02 allelerinin homozigotluğu durumlarında ortaya çıktığının aile çalışmalarında gösterildiği vurgulanmıştır. ${ }^{[13]}$ Bizim çalışmamızda ise HLA tipleme metodumuz ve kitlerimiz homozigotluk analizi tespit etmeye uygun olmadığından çalışmamızda rapor edilememiştir.

\section{Sonuç}

Çalışmamızdaki DQ2/DQ8 genotip ve allel dağılım oranları ülkemizde yapılan çalışma sonuçlarıyla daha fazla benzerlik göstermektedir. Çölyak hastalığı çevresel ve genetik etkiler altında ortaya çıkabilen multifaktöriyel bir hastalıktır. Çölyak hastalığı; HLA genleri ve kronik inflamatuar hastalık arasındaki ilişkinin incelenmesi için öncü bir model oluşturmaktadır. Ancak bu ilişkinin farklı toplum, ırk ve etnik gruplara göre değişiklikler gösterebileceği unutulmamalıdır.

Çıkar çatışması: Bildirilmemiştir.

\section{Kaynaklar}

1. Vidales MC, Zubillaga P, Zubillaga I, Alfonso-Sanchez MA. Allele and haplotype frequencies for HLA class II (DQA1 and DQB1) loci in patients with celiac disease from Spain. Hum immunol 2004;65:352-8.

2. Wu J, Xia B, von Blomberg BM, Zhao C, Yang XW, Crusius JB, et al. Coeliac disease in China, a field waiting for exploration. Rev Esp Enferm Dig 2010;102:472-7.

3. Kuloglu Z, Doganci T, Kansu A, Demirceken F, Duman M, Tutkak $\mathrm{H}$, et al. HLA types in Turkish children with celiac disease. Turk J Pediatr 2008;50:515-20.

4. Neuhausen SL, Weizman Z, Camp NJ, Elbedour K, Sheffield VC, Zone JJ, et al. HLA DQA1-DQB1 genotypes in Bedouin families with celiac disease. Hum immunol 2002;63:502-7. 
5. Walkowiak J, Blask-Osipa A, Lisowska A, Oralewska B, Pogorzelski A, Cichy W, et al. Cystic fibrosis is a risk factor for celiac disease. Acta Biochim Pol 2010;57:115-8.

6. Tjon JM, van Bergen J, Koning F. Celiac disease: how complicated can it get? Immunogenet 2010;62:641-51.

7. Clot F, Babron MC. Genetics of celiac disease. Mol Genet Metab 2000;71:76-80.

8. Costantini S, Rossi M, Colonna G, Facchiano AM. Modelling of HLA-DQ2 and its interaction with gluten peptides to explain molecular recognition in celiac disease. J Mol Graph Model 2005;23:419-31.

9. Alarida K, Harown J, Di Pierro MR, Drago S, Catassi C. HLA-DQ2 and -DQ8 genotypes in celiac and healthy Libyan children. Dig Liver Dis 2010;42:425-7.

10. Tuysuz B, Dursun A, Kutlu T, Sokucu S, Cine N, Suoglu O, et al. HLADQ alleles in patients with celiac disease in Turkey. Tissue antigens 2001;57:540-2.

11. Megiorni F, Mora B, Bonamico M, Barbato M, Nenna R, Maiella G, et al. HLA-DQ and risk gradient for celiac disease. Hum immunol 2009;70:55-9.

12. Tollefsen S, Arentz-Hansen H, Fleckenstein B, Molberg O, Raki M, Kwok WW, et al. HLA-DQ2 and -DQ8 signatures of gluten T cell epitopes in celiac disease. J Clin Invest 2006;116:2226-36.

13. Megiorni F, Pizzuti A. HLA-DQA1 and HLA-DQB1 in Celiac disease predisposition: practical implications of the HLA molecular typing. J Biomed Sci 2012;19:88.

14. Ceylan G, Tekedereli İ. Çölyak Hastalığı Olan Bir Ailede HLA Tiplendirmesi. Gazi Tıp Derg 2009;20:181-3.

15. Piccini B, Vascotto $M$, Serracca $L$, Luddi A, Margollicci MA, Balestri $P$, et al. HLA-DQ typing in the diagnostic algorithm of celiac disease. Rev Esp Enferm Dig 2012;104:248-54.

16. Castro-Antunes MM, Crovella S, Brandao LA, Guimaraes RL, Motta $M E$, Silva GA. Frequency distribution of HLA DQ2 and DQ8 in celiac patients and first-degree relatives in Recife, northeastern Brazil. Clinics (Sao Paulo) 2011;66:227-31.

17. Karell K, Louka AS, Moodie SJ, Ascher H, Clot F, Greco L, et al. HLA types in celiac disease patients not carrying the DQA $1{ }^{*} 05$ $\mathrm{DQB1}{ }^{* 02}$ (DQ2) heterodimer: results from the European Genetics Cluster on Celiac Disease. Hum immunol 2003;64:469-77.

18. Biagi F, Bianchi PI, Vattiato C, Marchese A, Trotta L, Badulli C, et al. Influence of HLA-DQ2 and DQ8 on severity in celiac Disease. J Clin Gastroenterol 2012;46:46-50.

19. Tumer L, Altuntas B, Hasanoglu A, Soylemezoglu O, Arinsoy T. Pattern of human leukocyte antigens in Turkish children with celiac disease. Pediatr Int 2000;42:678-81.

20. Cintado A, Sorell L, Galvan JA, Martinez L, Castaneda C, Fragoso T, et al. HLA DQA $1{ }^{*} 0501$ and DQB1*02 in Cuban celiac patients. Hum immunol 2006;67:639-42. 